\title{
Chapter 28 \\ Does Justice Require De-extinction of the Heath Hen?
}

\author{
Jennifer Welchman
}

\begin{abstract}
It is often argued that we "owe it" to species driven to extinction "to bring them back." Can justice really require us to make restitution for anthropogenic extinctions? Can it require de-extinction? And if so, can justice require us to attempt the North American Heath Hen's de-extinction? I will first review the types of deextinction technologies currently available. I will then discuss the criteria used to determine when restitution is owed for injuries as well as the special challenges arising when (i) victims are wild animals and (ii) are extinct. After arguing that restitution may be due for some extinctions and that de-extinction would sometimes be an appropriate means, I apply these arguments to the case of the Heath Hen.
\end{abstract}

\subsection{Introduction}

By all means, bring the Heath Hen back and undo the horrible mistake of letting this animal go extinct in the first place. We caused its extinction; we are responsible for bringing it back. (Dan 2014)

Human beings are responsible for many species' extinctions since our own first appeared on the planet. However, it was not until the late eighteenth century that scientists realized that species could become globally extinct (Barrow 2009). It was another century before the possibility of anthropogenic extinctions was recognized (Cowles 2012). After the disappearance of the Dodo and the Great Auk, events in which humans were clearly implicated, government regulations to control overhunting and fishing of game birds and animals were expanded in many European countries and extended to their colonies abroad but did little to diminish the impact of habitat disruption and over-hunting on many species. By the end of the nineteenth century, societies for the protection of wildlife, especially birds, began to

\footnotetext{
J. Welchman $(\bowtie)$

University of Alberta, Edmonton, AB, Canada

e-mail:welchman@ualberta.ca

B. Bovenkerk and J. Keulartz (eds.), Animals in Our Midst: The Challenges

of Co-existing with Animals in the Anthropocene, The International Library

of Environmental, Agricultural and Food Ethics 33,

https://doi.org/10.1007/978-3-030-63523-7_28
} 
form in Europe and North America. Great Britain's Society for the Protection of Birds (later the Royal Society for Protection of Birds) began in 1892, followed by the Vogelbescherming Nederland (1899), the Audubon Society (1905), and La Ligue pour la protection des oiseaux (1912) (Boardman 2006).

In 1908, the United States began one of its first serious attempts to prevent an extinction with the creation of a sanctuary for the Heath Hen on the island of Martha's Vineyard (Massachusetts). The Heath Hen, a ground-dwelling bird, related to Prairie Chickens, had been extirpated from the mainland in the 1870s. Predictions for the remnant population on Martha's Vineyard were so dire that a sanctuary was created to reduce the pressure of hunting and habitat disturbance. The sanctuary reduced these pressures but only within its 612 acres. In the 1920s, the Heath Hen population went into a decline from which it never recovered. The last Heath Hen, Booming Ben, disappeared in 1932. Henry Hough, editor of a local newspaper, blamed human chauvinism for the bird's demise.

The gospel of conservation, it is said, has won the day. We know this is not true...Is nothing to follow the extinction of this bird except one more lesson in conservation for school books and a sentimental mourning? (Hough 1933; see Barrow 2009)

The Revive \& Restore Organization has been investigating an alternative: deextinction, the genetic engineering of an approximation of the Heath Hen for eventual release onto islands around Martha's Vineyard (Revive and Restore).

Revive and Restore's Heath Hen Project is one of several "de-extinction" ventures whose goal is the replication of extinct species. Supporters argue that they offer many potential benefits. First, conservationists could have new tools for slowing or reversing biodiversity losses. Second, de-extinct Ivory-Billed Woodpeckers, Moa, and Tasmanian Tigers would stimulate eco-tourism whose profits could bankroll protections for endangered species. Third, improvements in gene-editing techniques could have spillover benefits for human health, boosting the development of gene therapies. Supporters have also argued that de-extinction is worth pursuing for another kind of reason, as a means to right historical wrongs. As Dr. Jeffrey Johnson, a Heath Hen Project advisor put it, "These species have either gone extinct, locally extinct, or on the verge of extinction primarily due to the actions of man, so I feel obligated that we should try to do whatever we can to prevent further extinction, and now with this technology maybe even bring back a species" (Brown 2015b).

This last argument is different in kind from the other three. The first three appeal to our desires for the future outcomes de-extinction is said to offer. Their persuasiveness is dependent upon our desiring those outcomes (and believing that deextinction can achieve them). By contrast, the last argument is "backward-looking". It invites conscientious reflection on our past actions from a moral point of view. If some anthropogenic extinctions morally wronged their victims or third parties, justice might demand restitution for them. And if de-extinction was an effective means of doing so in some cases, justice might require us to embrace de-extinction, independent of any desires we might have for the future.

Backward-looking appeals to restitutive justice are commonly made by champions of de-extinction projects. "If we can retrieve the animals or retrieve at least the 
appearance of the quagga," says a director of a South African effort to replicate this extinct zebra, "then we can say we've righted a wrong" (Page and Hancock 2016). ${ }^{1}$ The Australian Lazarus Project, whose founders hope to clone the extinct Gastric Brooding Frog, has been characterized as fulfilling "an ethical responsibility...to undo the harm that we have done in contributing to its extinction" (Smith 2017). Reversal of the anthropogenic extinctions of Tasmanian Tiger (or thylacine) and Passenger Pigeon have likewise been justified in moral terms: "Having hunted the thylacine to extinction, we owe it to the species to bring it back" and "we caused the extinction of the species... Now we have a moral obligation to bring [the Passenger Pigeon] back" (Pickrell 2018; Bethge 2013). ${ }^{2}$ Increasingly, these appeals are drawing attention from environmental philosophers. ${ }^{3}$ One of de-extinction's most persistent philosophical critics, Ben Minteer, has described it as "the most powerful" argument in favor of de-extinction offered by its proponents (Minteer 2014).

Minteer's claim is surprising when considered in light of recent debates in contemporary intergenerational ethics. Arguments for restitution to victims of historical injustices are always highly contentious when all the victims are dead (even when the victims are human beings). It is not clear how we can make restitution to the dead. Sometimes the victims of historical injustices have descendants. In these cases, claims for restitution, though politically controversial, are at least taken seriously. But while some extinct species have living relatives, few have any direct descendants. Is it plausible that we could have duties of justice to make restitution for anthropogenic extinctions? Would they require de-extinction? More specifically, might we have such a duty to the Heath Hen and, if so, would it require us to attempt the Heath Hen's de-extinction? These are the questions I will try to answer in this chapter. First, I will briefly review the three families of de-extinction techniques currently available. Next I will discuss the criteria used to determine when and to whom restitution is owed for injuries done to others, and the special challenges that arise when (i) victims are members of wild species and (ii) there are no living survivors. After arguing that restitution may be due for some kinds of anthropogenic extinctions and when de-extinction technologies might be the best means to employ, I will consider whether the Heath Hen's extinction is such a case.

The focus of this chapter throughout will be on the backward looking reparations argument for de-extinction as a duty of justice. So I shall not discuss forward-looking rationales, such as the potential to preserve biodiversity, stimulate eco-tourism, or improve human health. Nor shall I discuss the usual objections to them; that a deextinct species might threaten those which have inherited its former territory or that de-extinction projects may siphon public funding away from traditional conservation

\footnotetext{
${ }^{1}$ For information about the Quagga Project, visit: https://quaggaproject.org/.

${ }^{2}$ Interestingly, Ben Novak, the Passenger Pigeon Project scientist quoted in Bethge (2013), has been more hesitant about the application of this reasoning to other species. See Mitchell (2018).

${ }^{3}$ Most discussions ultimately conclude reparations arguments for de-extinction face insurmountable challenges of the sort to be discussed below, but not all. Pessimistic assessments include Rohwer and Marris (2018), Sandler (2014), Palmer (2012), Cohen (2014), Diehm (2015), Campbell and Whittle (2017), and Minteer $(2014,2015,2019)$. A more optimistic assessment is offered in Jebari (2016).
} 
efforts. Focusing on the Heath Hen project will help avoid distraction by these kinds of concerns. No candidate for de-extinction has less potential to become an ecological pest. The birds produced by the Heath Hen project would be non-migratory, grounddwelling birds initially restricted to barrier islands off the coast of Martha's Vineyard, islands free of any related species with which they might compete. Reintroduction in the species' historical range on the island of Martha's Vineyard would follow only after sufficient habitat was prepared. Currently, the project is privately funded. Were any public funds spent later to restore habitat for their reintroduction on Martha's Vineyard, traditional conservation goals would not suffer. ${ }^{4}$

\subsection{De-Extinction Techniques}

Modern medical technology is sometimes credited with restoring the 'clinically dead' back to life. What is actually reversed is a dying process, not death. Modern medicine can sometimes bring the dying back from death's door but cannot restore those who have already passed through it. Press reports sometimes describe de-extinction techniques as if they literally restored extinct animal species to life. As we will see, they too may sometimes help bring dying species back from extinction's door (no mean feat in itself) but cannot restore those which have already passed through it. "Deextinction" is an umbrella term which covers three families of breeding techniques developed to replicate the phenotype (form and appearance) and/or genotype of an extinct animal population. These include (i) back-breeding, (ii) cloning, and (iii) genome editing (Shapiro 2016).

Back-breeding is possible when members of a living species can trace their ancestry in part to an extinct species. Back-breeding projects try to replicate the phenotype of lost species by cross-breeding their hybrid descendants. The South African Quagga Project is one example. Its goal is to replicate the Quagga, an extinct subspecies of Plains Zebra, by cross-breeding hybrid Plains Zebra who retain traits from their distant Quagga ancestors. Back breeding has also been proposed to replicate the Pinta Island Tortoise, known internationally for its last survivor, "Lonesome George". Hybrid tortoises have recently been discovered on Floreana Island with Pinta Island Tortoise genes. Cross-breeding over several generations could produce offspring that closely replicate their Pinta Island ancestors (Beeler 2015).

Cloning projects try to replicate the genotype of a lost species by implanting the nucleus of a preserved cell from an extinct species into the egg cell of a related species (a process known as somatic cell nuclear transfer or SCNT). If the reconfigured egg cell begins dividing and develops into an embryo, the embryo can then implanted

\footnotetext{
${ }^{4}$ To prevent further distraction, I will also assume that the welfare interests of all the birds involved in the research are adequately met.

5I will use the term 'species' interchangeably with 'population' through out this paper as collective nouns for a group of closely genetically related animals that can interbreed. I shall not assume 'species' as wholes have interests or welfare distinct from that of their members.
} 
in the uterus of a related species for gestation. Cloning has been tried on a few occasions, with only partial success. An embryo was developed from preserved cells of the extinct Pyrenean Ibex but the clone died from congenital abnormalities shortly after birth (Kupferschmidt 2014). The Lazarus Project created living embryos from preserved tissue of extinct Gastric-Brooding Frogs, but none developed into adult frogs (Smith 2017).

Genome editing is a third technique that might be used in cases where there are no living hybrid descendants to be back-bred, no specimens sufficiently well preserved to make cloning possible, and/or, as in birds, where the target species' eggs are not amenable to SCNT. Scientists would edit the genome of a close living relative in order to replicate sequences distinctive of the extinct species they hoped to replicate. The edited cells would later be used to produce viable embryos. This is the method being researched by Revive \& Restore for the de-extinction of the Heath Hen.

Each method would replicate the extinct species' phenotype and/or genotype to some extent, but in no case would the offspring possess all and only the traits of the extinct species. Back-breeding hybrid Pinta Island tortoises cannot fully erase the genetic signature of their Floreana ancestors. ${ }^{6}$ The complexity of gene editing suggests that offspring would at best approximate the genomes of the target species. Heath Hens produced by editing the genome of Prairie Chickens would possess the traits of a Heath Hen-Prairie Chicken hybrid rather than all and only those of historical Heath Hens. Even cloned animals will have hybrid traits, as they would inherit maternal mitochondria from the eggs used in the SCNT process.

Critics of de-extinction projects have argued that for this reason, de-extinct animals are unworthy for release into natural environments. De-extinct animals are variously described as hybrids, inauthentic, and worse: "engineered dopplegangers", "franken species and eco-zombies" and "technological artefacts, not members of any natural species” (Minteer 2015; Shultz 2016; Campbell 2017). We should not allow ourselves to be influenced by this sort of language. First, it is rooted in outdated ideas about species that have underwritten racist ideologies for centuries. The assumption that "miscegenation", the mixing of different species or races of beings, including human beings, results in unnatural or inferior "mongrel" offspring is a survival of pre-Darwinian essentialist ideas about the nature of species-which sadly persisted in Darwin's own work, where hybrids are described as outcomes of "illegitimate unions" and "unnatural crossing" (Darwin 1896). On this view, any so-called "human being" who has inherited Neanderthal genes is actually an impure hybrid who ought not be allow to procreate with purer, more authentic, human beings.

Second, it relies on equally questionable assumptions about the value of the "natural" versus the "artificial". If de-extinct Heath Hens are technological artefacts, what then are the thousands of children born every year from in vitro fertilized donor eggs? Pseudo-human franken-children who should be kept apart from their more authentic, naturally-conceived counterparts? Of course we should be concerned about

\footnotetext{
${ }^{6}$ Humans have not had Neanderthal reproductive partners in over 30,000 years, yet from 1 to $4 \%$ of the genetic material of their hybrid human descendants remains Neanderthal (Sánchez-Quinto and Lalueza-Fox 2015).
} 
the potential consequences of releasing replicated Heath Hens into natural areas. From an ecological perspective, it matters enormously whether they can behave as good ecological citizens. However, the purity of their lineage and the manner of their conception have no comparable significance. Thus for current purposes, I will assume that at least some replicas of extinct species would be good environmental citizens and that a de-extinct Heath Hen could be one of them.

\subsection{Can Restitutive Justice Be Extended to Wild Animals?}

Common sense conceptions of justice require that those responsible for causing avoidable and unjustifiable harm to others' welfare offer restitution. If the injury took the form of misappropriation of material goods, the person responsible should restore those goods to the individuals entitled to them. If, on the other hand, direct restoration is impossible, then the person responsible should offer reparations to compensate the victim by other means. Material reparations are not due unless four criteria are met: the perpetrator was a competent moral agent, the injury could have been avoided, the victim was an individual capable of suffering, and making material reparations is possible. Wild deer do not owe farmers reparations for the field crops they damage because wild deer are not moral agents. If the farmers' employees could not have prevented the deer from entering those fields, they do not owe their employers reparations. The damaged crops are owed nothing because they are incapable of suffering. And finally, because 'ought' implies 'can', material reparations are not owed if they cannot be made.

Most now agree that if an animal is capable of suffering, we have a moral duty to avoid causing it to suffer. Many go further, arguing that animals have rights not to be made to suffer or be confined by human beings. However, most of these discussions focus on domesticated animals. Sentient wild animals possess the same claims to moral standing as their domestic counterparts. But some doubt that we can extend these duties to wild animals without contradiction. Many wild animals suffer from illness and predation, conditions that could be mitigated if we forced sick animals to accept medical treatment or confined and/or exterminated predators. In other words, as Martha Nussbaum points out, when it comes to wild animals, acting for the good of one species often entails acting against the good of another. She asks:

Should humans police the animal world, protecting vulnerable animals from predators? ... The death of a gazelle after painful torture is just as bad for the gazelle when torture is inflicted by a tiger as when it is done by a human being. That does not mean that death by tiger is as blameworthy; obviously it is not. But it does suggest that we have similar reasons to prevent it, if we can do so without doing greater harms...The problem is that the needs of the predatory animal must also be considered, and we do not have the option of giving the tiger in the wild a nice ball on a string to play with. (Nussbaum 2006, 379) 
Clare Palmer argues this is just one of "a number of difficulties raised by the importing of claims about justice from human/human to human/animal relations". 7 Our concepts of justice arose in response to our need to manage human social relationships. Many domestic animals have roles in those relationships, and to the extent they do, she argues, their roles entitle them to consideration. This is not the case with wild animals. Palmer $(2010,89)$ writes:

Fully wild animals...do not have such relations with humans; so duties to assist them are not generated on these grounds. There is no analogy to current or historical unfairness or injustice (or, indeed, fairness or justice) about the states in which wild animals find themselves. Inasmuch as they live without human contact, they are outside the realm of justice altogether. (Palmer 2010, 87)

Since wild animals fall outside the scope of our concepts of justice, Palmer suggests that human beings do not owe wild animals reparations either for harms inflicted by other wildlife or by human interventions in their environments. In her view, talk of human beings owing reparations to wild animals is confused or metaphoric. She argues that at most we can have "reparation-like special obligations" to act benevolently towards those animals, chiefly domesticated, whom we have made vulnerable through our interventions in their lives (Palmer 2010, 96).

However, as Palmer notes, "justice" is used to refer to a host of related principles: economic, distributive, retributive, restorative, social and political. There would be enormous difficulties in trying to extend all of these many principles of justice to animals generally, let alone wild animals specifically. The basic common-sense principle of restitutive justice seems another matter. Meeting the criteria for claims of restitutive justice on sentient animals' behalf does not seem inherently problematic - at least not in cases where their injuries were avoidable, no overriding moral reasons compelled the acts responsible, and there was some practical means of making restitution to the animals concerned.

Palmer might reply that this is an exaggeration. Meeting all four criteria when the "victim" is a wild animal is not as simple as I have made it appear. In most cases, we face huge epistemic challenges in determining whether and to what extent our avoidable interactions with wild animals harm them. Most wild creatures' vulnerability to suffering is consequence of life in the wild, not their interactions with human beings. Premature death from illness, injuries, and predation is a norm in the wild. As Mark Sagoff famously remarked:

The principle of natural selection is not obviously a humanitarian principle; the predator-prey relation does not depend on moral empathy. Nature ruthlessly limits animal populations by doing violence to virtually every individual before it reaches maturity. (Sagoff 1984, 299)

Some of the animals pursued by hunters and anglers may go on to lead long, reasonably healthy, and enjoyable lives if not captured and killed. Others would not. They would die soon anyway from any of a myriad of causes, many of them painful. In shooting a deer, a hunter may regrettably shorten a life worth continuing or,

\footnotetext{
${ }^{7}$ See also a related argument in Anderson (2004).
} 
alternately, mercifully end its suffering from disease, injuries, or parasites. The wellintentioned angler who throws a trout back into a stream has no real way of knowing if she has spared its life or thrown it into the mouth of a predator.

There are two ways one might respond to the issues Nussbaum and Palmer raise. One would be to argue that we cannot have the same sorts of moral duties towards wild animals that we have towards domesticated animals, because we know too little of the circumstances of any particular wild creature to determine whether our interventions in its affairs would be helpful or harmful overall. 'Ought' implies 'can'. If we can never be sure that any given act will actually injure a wild animal's life prospects overall, we cannot be obliged to avoid harming them nor owe them restitution if we do. The other would be to argue that the epistemic challenges wild animals present do not change the kinds of duties we have to them, vis a vis domesticated animals. It simply changes the methods we are warranted in using to evaluate harms we cause. Our familiarity with and control over the lives of domesticated and captive animals usually ensures we can estimate how any particular action is likely to affect them. Our lack of knowledge about or control over fully wild animals routinely ensures we cannot. But this do not mean there are no measures available to us to evaluate our conduct towards wild animals. Population measures can provide a proxy by which to make rough estimations of whether particular practices are harmful to wildlife.

Different measures of harm can be used to determine what justice requires when we injure others. These measures fall into two broad categories: comparative and noncomparative. Comparative measures determine how much worse off an individual is after an injurious event, either by comparing that individual's condition prior to and following the event (a historical comparison) or by comparing her condition after the event with how it would have been had the event not occurred (a counterfactual comparison). ${ }^{8}$ Provided one has sufficient information about an individual's circumstances to make comparisons of either type, one can arrive at fine-grained analyses of the degree of harm a party has suffered from another's intentional or negligent actions. When the victims are individuals or members of groups about whose prior histories and particular circumstances we know little, historical and counter-factual comparisons become impractical. In these cases, we turn to noncomparative measures. We assume that certain states are intrinsically bad states for individuals (e.g., physical debilitation, mental suffering, loss of autonomy) and if the intentional or negligent act has imposed such states on those affected, they are said to be harmed. (Shiffrin 2012; Harman 2009; Hanser 2008) Because non-comparative measures rely on pre-determined lists of intrinsically bad states and do not measure ancillary harms victims may undergo, their results are less fine-grained than comparative measures. To do victims full justice in assessing claims for restitution, comparative measures are preferable. But when we lack the information required to employ them, non-comparative measures become an alternate if cruder means of proceeding.

We rarely know enough about the lives of wild species to measure the effects of our acts upon individual animals comparatively, even those which have received

\footnotetext{
${ }^{8}$ For background, see Perry (2003). For criticism and defense of comparative accounts of harm, see, respectively, Norcross (2005) and Klocksiem (2012).
} 
scientific study. Often our only basis for determining the effects of human activity upon them are rough estimates of population trends. ${ }^{9}$ But this kind of information does provide a non-comparative means by which to gage statistically whether our interventions are imposing intrinsic evils on a species' members. Inability to obtain sufficient food, water, and shelter to grow to a reproductively viable age is surely an intrinsically bad state for any sentient being, human or nonhuman. Whenever it is evident that human practices are preventing a population from sustaining its numbers, we can be sure we are harming them in a non-comparative sense by denying its members, on average, access to the basic goods necessary to sustain their numbers. If those practices are avoidable, not required by overriding moral considerations, and mitigatable, I would argue all four criteria for a duty of restitutive justice to sentient species of wild animals can be met.

Using the effects of human activity on population numbers means that we will not owe reparations for every act that kills or displaces an individual animal, provided it is a member of a species whose individual welfare we cannot accurately assess. It will be the effects of our practices on that species' population levels that determine whether reparations can reasonably be claimed on that species' behalf. So it would seem that if a restricted season for hunting or angling did not diminish populations of the target species, restricted hunting and angling would not warrant reparations. Similarly, if human development of a natural area does not diminish populations of any wildlife displaced, then the displacement would not warrant restitution or reparations. However, if hunting, fishing, and development practices evidently do deny a population the means to sustain itself, those practices are harmful and may warrant reparations.

So we need not wait until a species becomes extinct to demand restitutive justice on its behalf. Extinction is not itself a kind of harm. Extinction is an indicator that a wild population has been harmed; i.e., suffered intrinsically bad states through denial of the basic natural goods by which it sustained itself. Conservation advocates have prima facie grounds for demanding restorative justice on a species' behalf as soon as (i) the population's numbers are shrinking and (ii) its losses are traceable to culpable human activity.

Restitutive justice claims become more urgent as a species' numbers shrink to levels below statistical norms for survival, especially when its genetic diversity has shrunk along with its numbers. ${ }^{10}$ Such a species is at risk of entering an extinction vortex; a state in which "an insidious mutual reinforcement can occur among biotic and abiotic processes such as environmental stochasticity, demographic stochasticity, inbreeding, and behavioural failures, driving population size downward to extinction" (Fagan and Holmes, 2006). If this harm is traceable to avoidable human behavior, to do justice to the victims, action should be taken to restore the basic natural goods to

\footnotetext{
${ }^{9}$ For an extended argument to this effect, see Delon and Purves (2018). See also Johanssen's 2019 discussion. I am prepared to grant that there are some species about which we have sufficient information to be sure that particular kinds of human interventions are directly harmful, but these are exceptions not the rule when it comes to the totality of sentient wild species on this planet.

${ }^{10}$ For an overview of the history and current methods of developing minimum viability population measures, including the "50/500" rule, see Stephens (2016).
} 
levels sufficient to allow the survivors to recover and sustain their typical numbers. In rare cases, justice might even require us to use de-extinction technologies to rescue a species already entering an extinction vortex.

One basic good essential for sexually reproducing species to sustain their numbers are viable reproductive partners. Currently neither of the two surviving female Northern White Rhinos has access to a viable breeding partner because no males exist. As this state is a direct result of culpable human action, some believe that frozen tissue from Northern White Rhinos should be used to clone replacement breeding stock sufficient for the population to recover to sustainable levels. ${ }^{11}$ A similar argument has been made regarding Black-footed Ferrets. As all surviving Black-footed Ferrets are descended from just seven survivors, it is feared that their low numbers and diminished genetic diversity put them at imminent risk of inbreeding depression and reproductive failure. In other words, they may be on the brink of an "extinction vortex", even while their needs for other basic natural goods are being met. This might be forestalled by providing Black-Footed Ferrets with the genetically diverse reproductive partners they currently lack, if it becomes possible to produce offspring by cloning the tissue of preserved ferrets. Another candidate might be the Ivory-Billed Woodpecker. Unconfirmed observations have persuaded some that the species may persist but in numbers so low, extinction must be imminent. Were it possible to edit the genome of a related species of woodpecker in order to provide surviving Ivory-Billed Woodpeckers with viable partners, their extinction might be forestalled. Had these technologies been available in the late 1920s, we might have used them to provide reproductive partners for the last three Heath Hens, all male. As we were responsible for their plight, we would have owed it to them to make the attempt. Might we owe it them now?

\subsection{Special Challenges Posed by Historical Injustices}

Prior to the Heath Hen's extinction, our duties of restitutive justice might have been fulfilled by restoring the basic goods denied them by human development on Martha's Vineyard, such as food, shelter from predation, reproductive partners, and the like. As simple restoration of these goods is no longer possible, the question of compensatory reparations arises. Whether reparations could be due in this case is complicated by the fact that the injustice done is 'historical', i.e., the injustice occurred so long ago none of the parties directly involved remain alive. As with other cases of historical injustice, it may not be clear that all four criteria for material reparations can be met. Who can be obliged to offer reparations and to whom would they be due? If we cannot

\footnotetext{
11“They are at the brink of extinction only due to human activity," says Jan Stejskal, director of communication and international projects at the Dvůr Králové Zoo in the Czech Republic, where Sudan lived from 1975 until 2009. "If we have the techniques or methods to assist them to survive, I think it is our responsibility to utilize them" (quoted in Potenza 2018).
} 
provide adequate solutions to these challenges, attempts to provide reparations for anthropogenic extinctions would be purely symbolic. ${ }^{12}$

Consider the loosely analogous case of the injustices perpetrated by the European colonizers of another island, Newfoundland, north of Martha's Vineyard, off Canada's Atlantic coast. European settlement of Newfoundland in the eighteenth and nineteenth centuries harmed the indigenous Beothuk community by displacing them from fishing grounds on which they depended for their survival, competing with them for forest resources, and introducing diseases to which the Beothuk had no resistance. Shanawdithit, the last known survivor of Beothuk island community died in 1829. Some would argue that any attempt to make reparations to the Beothuk community now would be merely symbolic. The Beothuk community is gone as are those responsible for the injuries that caused the community's dissolution. The dead no longer exist. To extract reparations from the colonists and transfer them to the victims, would involve "backward causation". In other words, we would have to be able to go back in time and change the past. As this is impossible, no agent, individual or collective, owes material reparations to the Beothuk. By the same logic, one might argue, no one is now obliged to make material reparations for the wrongs done the Heath Hen by the European colonizers of Martha's Vineyard.

The developing literature on intergenerational ethics suggests that these are not insurmountable challenges. Consider the claim that no one is now responsible for the wrongs done the Beothuk. This might seem correct regarding infractions committed by deceased individuals acting alone. It is not so obviously correct when those responsible acted on behalf of, at the behest of, and/or with the consent of transgenerational collective agents, such as corporations, societies, and political states. These kinds of collectives are not 'natural' persons and so do not naturally possess either moral agency or rights. Nevertheless many are granted artificial agency and rights, by legislation or regulation, to facilitate their provision of valuable services and to ensure accountability for injuries they cause. The agency granted is moreover often transgenerational, a long standing legal and social practice which we have good reason to support (Thompson 2009). Were there no institutions whose agency did not transcend generational change, the force of treaties, bequests, and corporate and other contracts would not survive the lives of their signatories.

This means that if a historical injustice is traceable to members of transgenerational institutions who were acting in accordance with that institution's policies or directives and that transgenerational institution still exists, then there will be no difficulty in determining who owes reparations in that case. Applied to the case of historical injustice done the Beothuk, the responsible party would be Canada. Even though Canada did not exist in its current political form until 1867 or include Newfoundland until 1949, the nation was created by and from transgenerational institutions responsible for colonizing Newfoundland. As well as inheriting various rights,

\footnotetext{
${ }^{12}$ This does not entail that symbolic reparations could not or should not be made. The symbolic benefits of governmental apologies for past injustices, even those leaving no survivors, can have enormous social benefits. However, symbolic gestures are not meaningful for animals, so I shall not discuss them further here.
} 
possessions, and territories of its predecessors, it also inherited certain obligations. As Tracy Isaacs (2014) argues:

Canada is an enduring and identifiable collective entity, causally connected to the history of wrongdoing against First Nations. For these reasons, Canada and its [non-indigenous] citizens share in blame for past wrongs.

If we apply the same reasoning to the Heath Hen, then the State of Massachusetts and the local governments of Martha's Vineyard, are the transgenerational agents responsible both for the harms leading to the Heath Hen's demise and any reparations owed.

A second challenge in cases of historical injustice is determining who is entitled to claim reparations after the original victims are dead. In some cases, the original victims were themselves members of transgenerational collectives that still exist. In these cases, the recipients to whom reparations should be paid are easily identified. For example the indigenous residents of Martha's Vineyard, the Wampanoag Tribe of Gay Head (Aquinnah), is such a collective. In 1987, the Wampanoag won a settlement from the United States government for historical injustices done their ancestors, including wrongful appropriation of territory by earlier generations of non-indigenous settlers. As the Heath Hen played a role in the traditional diet of the Wampanoag, arguably the United States government's failure to preserve the Heath Hen was a further wrong for which the Wampanoag should receive compensation. Unfortunately, we cannot use this approach to establish a duty of reparations to the Heath Hen themselves (as opposed to a duty to the Wampanoag community regarding the Heath Hen.) Populations of wild animals are not organized collectives or institutions able to exercise transgenerational agency.

Living descendants of the victims of historical injustices (including descendants of indirect victims who suffered collateral damages) are another potential source of legitimate claimants to reparations. For example, the United Nations 2005 resolution, "Basic Principles and Guidelines on the Right to a Remedy and Reparation for Victims of Gross Violations of International Human Rights Law and Serious Violations of International Humanitarian Law", states that "where appropriate, and in accordance with domestic law, the term 'victim' also includes the immediate family or dependants of the direct victim" (United Nations 2005). In practice, legal enforcement is piecemeal and highly variable, however the principle that descendants have legitimate moral claims for reparations for wrongs done their predecessors is widely accepted. There are at least two ways one might apply this principle to the case of the Beothuk. First one could follow up reports from the coastal Mi'kmaq that many Beothuk fled Newfoundland before the final dissolution of their community. It may yet be possible to identify descendants of these refugees who would have a moral claim to reparations. Second, one could follow up on the effects of the dissolution of the Beothuk community on its Mi'kmaq neighbors. Losing access to a former trading partner very likely had negative consequences for neighboring Mi'kmaq communities, undermining their welfare and social and economic independence. If so, then in virtue of this collateral damage, descendants of these Mi'kmaq families would have a moral claim to material reparations. 
Clearly we cannot use the first of these two strategies to generate reparations claims on behalf of extinct species, such as the Heath Hen, which have no descendants. Nevertheless, the second could potentially warrant moral claims for some non-human species affected by the anthropogenic extinctions of others. Imagine the human practices responsible for the Heath Hen's demise inadvertently harmed other sentient species in ways that continue to depress their descendants' abilities to maintain their populations. Alternately, imagine the Heath Hen provided ecosystem services important to a second species whose numbers have been depressed ever since the Heath Hen disappeared. In each scenario, there would be descendants of individuals who had suffered collateral damages, directly or indirectly, from the culpable harm done the Heath Hen.

Some critics of reparations arguments for historical injustices have worried that these strategies are undermined by the infamous "non-identity problem". Derek Parfit (1987) has shown that when we use comparative conceptions of harm, trying to establish that individuals were harmed by events responsible for those individuals being born may be difficult or impossible. On the comparative measures of harm we employ for most human interactions, a person is harmed if she is made worse off than she was-or worse off than she would have been-had the harmful event not occurred. If we apply a comparative measures of harm to the situations of surviving descendants of Beothuk or to descendants of the Mi'kmaq affected by the dissolution of the Beothuk community, it might be impossible to establish that any were made worse off comparatively speaking. These individuals would probably never have been born had European settlers not driven the last Beothuk from Newfoundland. Their ancestors' lives would have been sufficiently different to ensure that most would have had children with different reproductive partners in each of the intervening generations. By this time, very probably, none of their descendants would ever have existed but for the wrongs done the Beothuk. So unless their lives are so bad as to be not worth living at all, it would seem that they cannot be said to be worse off comparatively speaking. ${ }^{13}$ Critics of reparations claims for anthropogenic extinctions believe the same is true for descendants of non-human species impacted by anthropogenic extinctions. If their identities were fixed by the events leading to those extinctions, we could not now claim those individuals were worse off comparatively speaking, unless their lives were so bad as not to be worth living at all (Palmer 2010, 2012; Rohwer and Marris 2018).

The non-identity problem does pose a challenge to some kinds of reparations claims involving human beings, specifically those which rely on comparative measures of harm. However, this problem rarely arises with historical injustices to wild animals. As noted above, with most wild animal populations, the only measures available to us are non-comparative. On non-comparative measures, all we need to determine is whether there is statistical evidence that the members of an animal population have been subjected to intrinsically harmful states. Population numbers are

\footnotetext{
${ }^{13}$ We are, of course, not restricted to using comparative measures even with human beings. When paradoxical conclusions like this result from employing comparative measures, others should be adopted.
} 
used for this purpose. If human practices are causing a population of wild animals to shrink, we have evidence that its members, by and large, are being denied access to vital basic goods. And if this harm could have been avoided, and was not compelled by overriding moral considerations, we also have grounds for claiming reparations on those animals' behalf.

\subsection{De-Extinction, Reparations, and the Heath Hen}

The efforts made to save the Heath Hen were piecemeal and inadequate. Hunting was never banned outside the grasslands refuge created in 1908. Ill-advised fire suppression reduced the quality of the habitat the refuge provided. Feral cats were allowed to roam freely, preying on fledglings. Chickens and introduced game birds competed for resources.

Other native ground dwelling birds, such as the Ruffed Grouse, have also diminished in numbers. Bobwhite Quail numbers have been maintained but only by restocking with captive reared birds. As the human practices that caused the Heath Hen's demise are evidently also harming descendants of these other species, then we appear to have grounds for recognizing a duty to make reparations to them; controlling feral cats for example, eliminating hunting perhaps, and improving fire management. At the same time, we have reason to dismiss this rationale as irrelevant. Our obligations to reform our practices are over-determined. If existing wildlife populations are struggling because of harmful human practices, we already have sufficient reason for concluding we should reform them; the fact that they are harmful now. We would have exactly the same reason, even if our practices had not caused the Heath Hen's extinction. These reasons suggest we have obligations to restore habitat, control feral cats, improve fire suppression techniques and reduce human development in areas critical to these species' survival, rather than recreating the Heath Hen.

De-extinction could be morally obligatory if it turned out that Heath Hens were a foundational species for the grassland ecosystems on which the Heath Hen and other species depended. Jeffrey Yule has argued that in cases where no other species is able to fill the ecological gap left following an extinction, we may have an obligation to provide the ecological communities impacted with "a sort of ecological artificial limb or prosthesis... to replace the amputated original" (Yule 2002). When we think of deextinction as a means to provide damaged ecological communities and co-dependent species with a prosthesis, "the quality of the replacement in duplicating the missing original would likely be a key consideration" (ibid.). That said, authenticity matters less than functionality. So it would not matter that recreated Heath Hens did not perfectly replicate their extinct "ancestors", provided they behaved in substantially similar ways. As he notes, "ecosystems, like people, are arguably far better off with prosthetics, particularly high quality prosthetics, than without them" (ibid.). Currently there is no other related species that can thrive in the conditions that suited the Heath Hen. This suggests that if replacing the Heath Hen's ecological function is essential to right wrongs done to other species on Martha's Vineyard, we might owe 
it to them (albeit not to Heath Hens themselves) to genetically recreate the Heath Hen. As it happens, there is no evidence that the Heath Hen played a foundational role in the grassland ecology of Martha's Vineyard.

That would seem to spell an end to the possibility of justifying its replication as an act of reparation. On closer examination, there is another party to whom reparations might be owed: the human residents of Martha's Vineyard. It is a standing grief to many that they will never enjoy the sight or sound of Heath Hens strutting and booming on their breeding grounds as earlier generations did. It is likewise a standing grief to others that they will never see a living Tasmanian Tiger, Passenger Pigeon, or Gastric Brooding Frog. Commenting on the Heath Hen Project, a local naturalist, Tom Chase confessed, "The truth is that my reasons for supporting this are completely emotional and value based" (Brown 2015b). Chase mourned the steady decline in avian biodiversity since his childhood:

Kestrels were so abundant on Martha's Vineyard one flew in my house once and perched at the end of my bed," he said. "It was a time, like my father's time, of freedom and abundance. So when I see a project like this," Chase remarked, "as a conservationist I'm tired of fighting for things and always losing. I want to get on the proactive side and not the reactive side. (Brown 2015b)

Chase is just one of hundreds of thousands of people around the world who mourn the aesthetic, cultural, emotional, and material losses that avoidable anthropogenic extinctions have caused them. That means that he and the others like him can claim to be worse-off than they would have been had their predecessors passed on the same natural legacy of biodiversity they themselves had received from earlier generations. When extinctions are as recent as the Heath Hen's, the non-identity problem is not an issue. There is little likelihood that all those mourning the heath Hen's extinction would not have been born had its extinction not occurred.

There may be species whose cultural importance is so great as to warrant reparations claims against any transgenerational agencies responsible for their (avoidable) extinction. And in some of these cases, replicating the lost species might be the most effective means of righting the wrongs done. There is little reason to think the Heath Hen played such a role in the lives of residents of Martha's Vineyard. The people most likely to have formed such a relationship with the bird are those who co-existed with it the longest, i.e., the Wampanoag. Had the Heath Hen played a particularly significant role in their culture, Massachusetts might owe it to them to support the Heath Hen project. As the Wampanoag have never made such claims, I take it that the Heath Hen's loss was not so culturally injurious as to warrant de-extinction in reparation.

In a letter to the Vineyard Gazette, which Minteer discusses, Stephen Kellert provides a different moral defense for the Heath Hen Project:

Restoring the heath hen offers us the chance for a moral reawakening. It provides us with an affirmative opportunity to restore our connection to the earth and contribute to the healing and beauty of the land. It offers Martha's Vineyard the extraordinary opportunity to lead as an inspiring example to America of how by living in right relation to nature we may flourish and achieve an ineffable and deepening connection to the larger community of life. (2014) 
Minteer is dismissive because he thinks Kellert is recommending the Heath Hen Project as a techno-fix, i.e., a technological 'bandage' that mitigates symptoms of a social problem but does not address its cause. Thus he fears that Kellert's recommendation may reinforce rather than correct the vices responsible for anthropogenic extinctions and environmental degradation. Minteer writes:

In fomenting the fantasy that we can erase the environmental abuses of the past by pursuing high-tech species revival technologies, promoters of de-extinction are inadvertently undermining the responsibility to learn the lessons of our environmental history. $(2015,15)$

Minteer's point is well-taken but I think he is missing Kellert's. Kellert does not present Heath Hen replication as a techno-fix that would make atoning for and reforming long-standing vicious attitudes towards nature unnecessary. What Kellert sees as an affirmative opportunity for a moral reawakening is what would happen afterwards: learning to live with Heath Hens. To live with Heath Hens, nonindigenous islanders would have to develop new virtues of care for this species and its environment. Virtuous dispositions cannot be created by mental fiat. It takes time and practice to cultivate new virtues and to express them effectively. Means of identifying one's blind spots and positive reinforcement for correcting them are both important for success. The project of learning to live with Heath Hens might be an excellent way of going about this. Gaps in community caring would be visible to all. Backsliding could not be hidden. Success would likewise be visible and a point of pride for the community, reinforcing their commitment to self-reform. Learning to live with Heath Hens could indeed be morally, culturally, and indeed spiritually transformative.

Some fear that such projects will prove morally hazardous by inducing public apathy towards rising rates of species extinctions from the mistaken belief that extinctions are always reversible. There is no empirical evidence to support this. By contrast, there is a great deal of evidence to support worries about the effects on public attitudes of feeling powerless in the face of large-scale environmental problems, which include apathy, disengagement, and denial (Moser 2008; Moser and Dilling 2012). Anthropogenic extinction is this kind of problem. What can I do to prevent mass extinction? Which alterations in my character or behavior would make a difference? How could I know if I was succeeding? If the residents of Martha's Vineyard were to commit themselves to learning to live with Heath Hens, they would have concrete answers to these questions. They would have to learn to treat these birds as fellow residents of the Martha's Vineyard, entitled, as human residents are, to respect for their ways of life, fair shares in the natural goods the island affords, and community support in times of need. Were the communities of Martha's Vineyard to succeed, the Heath Hen would be a source of pride that could sustain them in other conservation endeavors. Perhaps then, Hough would feel that the gospel of conservation was finally winning the day on Martha's Vineyard.

Kellert might be right. Perhaps the best way to find out is to give it try. If the Heath Hen project has the benefits he suggests, de-extinction could be well worth the effort. But as we are now in the terrain of forward-looking reasons for replicating species, I will leave such questions to others. 


\subsection{Conclusion}

I have argued that that we can have basic duties of restitutive justice to wild animals and that in some cases, these duties might require us to make reparations for harming them. The harms for which we can be morally liable are those we could predict before (and so avoid) or after the fact (and so make reparations). These include the imposition of states intrinsically bad for any sentient creature, caused by the denial of basic natural goods essential for life, as revealed by statistical measures of population trends. If a population is not succeeding in maintaining its numbers over time, and human practices are responsible, we have a prima facie case that our practices are causing that population harm. If it turns out that our practices were avoidable and not excusable in light of other more pressing moral claims, then there is a prima facie case for judging the harm caused as morally culpable and warranting material reparations.

As we cannot make material reparations to the dead, we do not owe reparations directly to extinct animals. We can make reparations to descendants of human and wild animal populations indirectly harmed by a culpable anthropogenic extinctions, so we may sometimes have an obligation to do so. In two kinds of cases, our obligations might require employing de-extinction techniques to generate replicas of extinct species if adequately developed techniques are available: cases in which recreating a species is the only way to make reparations for harm to another species of wildlife and cases in which recreating a species is the only way to make reparations for undermining a human culture. In both sorts of cases, duties to recreate extinct species are owed to the living members of other species, not the extinct species itself.

In only one case in which we could owe it directly to a species itself to 'bring it back'. When we are responsible for driving a species into an extinction vortex for lack of viable reproductive partners, we could in principle owe it to that species to 'bring it back' - albeit from extinction's door rather than extinction proper. In this rather small subset of cases, the reparations argument for using de-extinction techniques has real teeth.

Regrettably, the Heath Hen's extinction falls into none of these categories. No species on Martha's Vineyard will become extinct if we do not breed a new variety of Heath Hen. No human culture will fail. Genetic engineering cannot now rescue the Heath Hen from extinction. This does not mean that there are no good forwardlooking consequentialist arguments for breeding a new variety of Heath Hen. There may be many. What it does mean is that we are under absolutely no moral obligation to try. So until good forward-looking reasons present themselves, requiesce in pace Tympanuchus Cupido Cupido. 


\section{References}

Anderson, E. 2004. Animal rights and the values of nonhuman life. In Animal rights: Current debates and new directions, ed. C.R. Sunstein and M.C. Nussbaum, 277-298. New York: Oxford University Press.

Barrow Jr., M.V. 2009. Nature's ghosts: Confronting extinction from the age of Jefferson to the age of ecology. Chicago: University of Chicago Press.

Beeler, C. 2015. How an extinct species is being revived on the Galapagos Islands. Public Radio International (online). https://www.pri.org/stories/2015-12-15/how-extinct-spe cies-being-revived-galapagos-islands. Accessed July 4, 2019.

Bethge, P. 2013. Raising passenger pigeons from the dead. Spiegel Online. Available at https://www.spiegel.de/international/zeitgeist/scientists-aim-to-bring-the-passenger-pig eon-back-from-extinction-a-893744.html. Accessed July 4, 2019.

Boardman, R. 2006. The International politics of bird conservation. Cheltenham, UK: Edward Elgar.

Brown, S. 2014. Never say never; Heath Hen may get its boom back. Vineyard Gazette, April 3. https://vineyardgazette.com/news/2014/04/03/never-say-never-heath-hen-may-get-its-boomback?k=vg533e0e76735bb\&r=1. Accessed July 4, 2019.

Brown, S. 2015a. Heath Hen project advances quickly. Vineyard Gazette, March 5. https://vineya rdgazette.com/news/2015/03/05/heath-hen-project-advances-quickly. Accessed July 5, 2019.

Brown, S. 2015b. Heath Hen as gateway bird for de-extinction inches closer to reality. Vineyard Gazette, August 20. https://vineyardgazette.com/news/2015/08/20/heath-hen-gateway-bird-deextinction-inches-closer-reality. Accessed July 4, 2019.

Campbell, D. 2017. On the authenticity of de-extinct organisms, and the Genesis argument. Animal Studies Journal 6(1): 61-79. http://ro.uow.edu.au/asj/vol6/iss 1/5. Accessed July 5, 2019.

Campbell, D.I., and P.M. Whittle. 2017. Resurrecting extinct species. Cham, Switzerland: Palgrave Macmillan.

Cohen, S. 2014. The ethics of de-extinction. NanoEthics 8 (2): 165-178.

Cowles, H. 2012. A Victorian extinction: Alfred Newton and the evolution of animal protection. The British Journal for the History of Science 46 (4): 695-714.

Dan. 2014. Comment on Brown's Never say never; Heath Hen may get its boom back. Vineyard Gazette. https://vineyardgazette.com/news/2014/04/03/never-say-never-heath-hen-may-get-itsboom-back?k=vg533e0e76735bb\&r=1. Accessed July 5, 2019.

Darwin, C. 1896. The origin of species by means of natural selection or the preservation of favored races in the struggle for life, vol. 2. New York: D. Appleton \& Co. https://oll.libertyfund.org/tit les/darwin-the-origin-of-species-vol-2. Accessed December 4, 2019.

Delon, N., and D. Purves. 2018. Wild animal suffering is intractable. Journal of Agricultural and Environmental Ethics 31 (2): 239-260.

Diehm, C. 2015. Should extinction be forever? Restitution, restoration, and reviving extinct species. Environmental Ethics 37 (2): 131-143.

Fagan, W.F., and E.E. Holmes. 2006. Quantifying the extinction vortex. Ecology Letters 9: 51-60.

Hanser, M. 2008. The metaphysics of harm. Philosophy and Phenomenological Research 77 (2): 421-450.

Harman, E. 2009. Harm as causing harm. In Harming future persons: Ethics, genetics and the nonidentity problem, ed. M.A. Roberts and D.T. Wasserman, 137-154. Dordrecht: Springer.

Hough, H.B. 1933. The Heath Hen's journey to extinction, 1792-1933. Tisbury, MA: Dukes County Historical Society.

Isaacs, T. 2014. Collective responsibility and collective obligation. Midwest Studies in Philosophy 38 (1): 40-57.

Jebari, K. 2016. Should extinction be forever? Philosophy of Technology 29: 211-222.

Johanssen, K. 2019. To assist or not to assist? Assessing the potential moral costs of humanitarian intervention in Nature. Environmental Values 29(10): 29-45. 
Kellert, S. 2014. Inspirational Project. Vineyard Gazette, July 31. https://vineyardgazette.com/news/ 2014/07/31/inspirational-project. Accessed July 4, 2019.

Klocksiem, J. 2012. A defense of the counterfactual comparative account of harm. American Philosophical Quarterly 49 (4): 285-300.

Kupferschmidt, K. 2014. Can cloning revive Spain's extinct mountain goat? Science 344(6180): 137-138. https://science.sciencemag.org/content/344/6180/137.full. Accessed July 5, 2019.

List, C., and P. Pettit. 2011. Group agency: The possibility, design, and status of corporate agents. Oxford: Oxford University Press.

Mitchell, N. 2018. If extinct animals could be brought back from the dead, should we do it? $A B C$ News [Australian Broadcasting Company online] https://www.abc.net.au/news/science/2018-1216/de-extinction-species-thylacine-woolly-mammoth-passenger-pigeon/10616670. Accessed July 5, 2019.

Minteer, B.A. 2014. Is it right to reverse extinction? Nature 509 (7500): 261. https://doi.org/10. 1038/509261a.

Minteer, B.A. 2015. The perils of de-extinction. Minding Nature 8(1): 11-17.

Minteer, B.A. 2019. Promethean dreams. In The fall of the wild: Extinction, de-extinction, and the ethics of conservation, author B.A. Minteer, 97-118. New York: Columbia University Press.

Moser, S.C. 2008. More bad news: The risk of neglecting emotional responses to climate change information. In Creating a climate for change: Communicating climate change and facilitating social change, ed. S.C. Moser and L. Dilling, 64-80. Cambridge: Cambridge University Press.

Moser, S., and L. Dilling. 2012. Communicating climate change: Closing the science-action gap. In The Oxford handbook of climate change and society, ed. R. Norgaard, D. Schlosberg, and J. Dryzek, 161-174. Oxford: Oxford University Press.

Norcross, A. 2005. Harming in context. Philosophical Studies 123: 149-173.

Nussbaum, M.C. 2006. Frontiers of justice: Disability, nationality, species membership. Cambridge, MA: Harvard University Press.

Page, T., and C. Hancock. 2016. Zebra cousin went extinct 100 years ago: Now, it's back. CNN online. https://www.cnn.com/2016/01/25/africa/quagga-project-zebra-conservationextinct-south-africa/index.html. Accessed July 5, 2019.

Palmer, C. 2012. Can-And should-We make reparation to Nature?'. In The environment: Philosophy, science, ethics, ed. W.P. Kabasenche, M. O'Rourke, and M. Slater, 201-222. Cambridge, MA: MIT Press.

Palmer, C. 2010. Animal ethics in context. New York: Columbia University Press.

Parfit, D. 1987. Reasons and persons. Oxford: Clarendon Press.

Perry, S. R. 2003. Harm, history, and counterfactuals. Faculty Scholarship. Paper 1108. http://sch olarship.law.upenn.edu/faculty_scholarship/1108.

Pickrell, J. 2018. Return of the living thylacine. Cosmos Magazine, July 4. https://cosmosmagazine. com/biology/return-of-the-living-thylacine. Accessed July 5, 2019.

Potenza, A. 2018. Inside the high-tech plot to save the northern white rhino from extinction. The Verge, April 6. https://www.theverge.com/2018/4/6/17175936/northern-white-rhino-de-ext inction-stem-cells-sudan. Accessed July 5, 2019.

Revive \& Restore. n.d. Heath Hen project. https://reviverestore.org/projects/heath-hen-project/. Accessed July 6, 2019.

Rohwer, Y., and E. Marris. 2018. An analysis of potential ethical justifications for mammoth deextinction and a call for empirical research. Ethics, Policy \& Environment 21 (1): 127-142.

Sagoff, M. 1984. Animal liberation and environmental ethics: Bad marriage, quick divorce. Osgoode Hall Law Journal 22(2): 297-307. http://digitalcommons.osgoode.yorku.ca/ohlj/vol22/iss2/5. Accessed July 5, 2019.

Sánchez-Quinto, F and C. Lalueza-Fox. 2015. Almost 20 years of Neanderthal palaeogenetics: Adaptation, admixture, diversity, demography and extinction. Philosophical Transactions of the Royal Society B 370: 20130374. https://doi.org/10.1098/rstb.2013.0374. Accessed January 22, 2021.

Sandler, R. 2014. The ethics of reviving long extinct species. Conservation Biology 28 (2): 354-360. 
Shiffrin, S.V. 2012. Harm and its moral significance. Legal Theory 18: 357-398.

Shultz, D. 2016. Should we bring extinct species back from the dead? Science (online). https:// www.sciencemag.org/news/2016/09/should-we-bring-extinct-species-back-dead. Accessed July $5,2019$.

Shapiro, B. 2016. Pathways to de-extinction: How close can we get to resurrection of an extinct species? Functional Ecology 31 (5): 996-1002.

Smith, D. 2017. De-extinction research to feature on ABC TV. University of New South Wales Newsroom website. https://newsroom.unsw.edu.au/news/science-tech/de-extinction-research-fea ture-abc-tv. Accessed July 5, 2019.

Stephens, P. 2016. Population viability analysis. In Oxford bibliographies in ecology, ed. David Gibson. New York: Oxford University Press. https://doi.org/10.1093/obo/9780199830060-0142. Thompson, J. 2009. Intergenerational Justice. New York: Routledge.

Tuck, J.A. 2006. Beothuk. In The Canadian encyclopedia: Historica Canada. Last Edited June 20, 2019. https://www.thecanadianencyclopedia.ca/en/article/beothuk. Accessed July 5, 2019.

United Nations. 2005. Basic principles and guidelines on the right to a remedy and reparation for victims of gross violations of international human rights law and serious violations of international humanitarian law, U.N. Doc. E/CN. 4/2005/L. 48. https://www.ohchr.org/EN/Professional Interest/Pages/RemedyAndReparation.aspx.

Yule, J.V. 2002. Cloning the extinct: Restoration as ecological prostheses. Common Ground 1 (2): $6-9$.

Jennifer Welchman (Phd Johns Hopkins University) is a professor of philosophy at the University of Alberta, Canada. Her main areas of research are in ethics, the history of ethics, and environmental ethics. Her chief philosophical indulgence is aesthetics (including environmental aesthetics). Current research is focused upon virtue ethics, the moral philosophy of David Hume, and the ethical implications of new biotechnologies for conservation. She is the author of Dewey's Ethical Thought and editor of The Practice of Virtue: Classic and Contemporary Readings in Virtue Ethics. She is currently co-director of the Canadian Society for Environmental Philosophy.

Open Access This chapter is licensed under the terms of the Creative Commons Attribution 4.0 International License (http://creativecommons.org/licenses/by/4.0/), which permits use, sharing, adaptation, distribution and reproduction in any medium or format, as long as you give appropriate credit to the original author(s) and the source, provide a link to the Creative Commons license and indicate if changes were made.

The images or other third party material in this chapter are included in the chapter's Creative Commons license, unless indicated otherwise in a credit line to the material. If material is not included in the chapter's Creative Commons license and your intended use is not permitted by statutory regulation or exceeds the permitted use, you will need to obtain permission directly from the copyright holder. 